\title{
PENGELOLAAN SAMPAH HOME INDUSTRY BERBASIS PARTISIPATIF DI KELURAHAN KERANGGAN
}

\author{
Deasy Olivia ${ }^{1}$, Ida Ayu Sawitri Dian Mawarni², Harianto Hardjasaputra ${ }^{3}$, Ade Firmansyah ${ }^{4}$ \\ 1, 2,3,4 Institut Sains dan Teknologi Pradita
}

deasy.olivia@pradita.ac.id, ida.ayu@pradita.ac.id, harianto.hardjasaputra@pradita.ac.id, ade.firmansyah@pradita.ac.id

\begin{abstract}
Abstrak
Kualitas lingkungan merupakan hal yang sedang digalakan untuk mewujudkan lingkungan yang ramah dan sehat. Namun, dalam penerapannya hal tersebut belum tercapai.Salah satu penyebab menurunnya kualitas lingkungan adalah sampah. Sampah yang tidak dikelola dengan baik mengakibatkan berbagai permasalahan bagi masyarakat dan lingkungan, yakni mengganggu kesehatan masyarakat, pencemaran lingkungan dan tanah, dan berpotensi menimbulkan bencana. Sampah yang tidak dikelola dengan baik disebabkan oleh kurangnya kesadaran dan pengetahuan masyarakat tentang cara mengelola sampah,dan kurangnya perhatian dari pihak pemangku kepentingan mengenai sistem manajemen pengelolaan sampah. Kelurahan Keranggan merupakan kawasan permukiman desa yang memiliki potensi home industry dan cukup bertahan. Namun, kawasan permukiman ini belum memiliki sistem pengelolaan sampah yang baik. Kurangnya kesadaran dan pengetahuan masyarakat tentang cara mengelola sampah mengakibatkan banyaknya sampah yang berserakan di kawasan permukiman ini. Kegiatan pengabdian kepada masyarakat ini bertujuan untuk mengedukasi masyarakat tentang cara mengelola sampah yang baik, menambah nilai guna sampah,dan membangun perilaku peduli lingkungan, menggunakan metode sosialisasi berbasis partisipatif dan media tepat guna yang informatif. Dari hasil kegiatan ini dapat disimpulkan bahwa pengelolaan sampah home industry dapat dilakukan apabila telah memahami jenis sampah,cara memilah sampah berdasarkan jenis sampah, sistem pengelolaan sampah, dan manfaat sampah menjadi barang yang tepat guna.
\end{abstract}

Kata Kunci : Kualitas Lingkungan, Pengelolaan Sampah, Partisipatif

\section{PENDAHULUAN}

Kualitas lingkungan merupakan salah satu isu yang saat ini sedang digalakan untuk mewujudkan lingkungan binaan yang ramah dan sehat. Namun, dalam kenyataannya hal tersebut belum tercapai. Hal ini terlihat dari kualitas hidup (Quality of Life) masyarakat yang masih rendah. Lingkungan binaan sebagai tempat bermukim dan beraktivitas bagi masyarakat juga belum memiliki kinerja permukiman yang tinggi. Salah satu aspek untuk menilai sebuah kinerja permukiman adalah aspek lingkungan (Olivia, Deasy, Setioko,Bambang, Purwanto,Edi, 2015). Salah satu penyebab menurunnya kualitas lingkungan dan konerja permukiman adalah permasalahan terkait sampah. Sampah setiap hari dihasilkan baik yang berasal dari limbah rumah tangga maupun sampah industri baik sampah organic maupun sampah non organik. Namun, hal yang memprihatinkan akibat dari sampah ini adalah bahwa sampah yang dihasilkan tidak dikelola dengan baik. Sampah yang berserakan dan dibiarkan terus-menerus mengganggu kesehatan serta menimbulkan bau yang tidak sedap, bahkan Lingkungan Hidup dan Kebencanaan 1 
semakin banyak tumpukan sampah yang berserakan dapat mengakibatkan bencana. Kurangnya kesadaran masyarakat tentang pentingnya menjaga kebersihan dan kesehatan lingkungan, serta didukung oleh minimnya pengetahuan mengenai cara mengelola sampah semakin menambah permasalahan menurunnya kualitas lingkungan.

Sampah adalah sisa atau barang buangan yang sudah tidak digunakan lagi oleh pemiliknya. Sampah secara umum dibagi menjadi 2(dua) jenis, yaitu sampah organic dan anorganik. Sampah organic tergolong sampah yang mudah didaur ulang dan dapat berasal dari limbah rumah tangga seperti sayur dan buah-buahan. Sedangkan sampah anorganik adalah sampah yang tidak dapat diurai, sehingga membutuhkan waktu yang lama untuk dapat diuraikan ( (Maulana,Fajar.M, Taufiq Agus, 2015).

Kota Tangerang Selatan adalah salah satu kota yang menyumbang sampah cukup besar. Dalam satu hari, kota ini mampu memproduksi sampah sekitar 250-300 ton sampah per hari( Setiawan dalam Wartakotalive.com, 26 Oktober 2018) Menurut Kabid Persampahan Dinas Lingkungan Hidup Tangerang Selatan, Wismansyah, jika dihitung per tahun, warga Tangerang Selatan membuang sampah 1.095 .000 per tahun.(Tohir dalam Tribun Jakarta.com, 3 Januari 2019).

Kelurahan Keranggan merupakan salah satu permukiman desa yang masih bertahan di tengah arus modernisasi dan perubahan spasial maupun non spasial. Kebertahanan permukiman Kelurahan Keranggan ini juga didukung oleh potensi home industry yang diproduksi oleh ibu-ibu rumah tangga. Adapun produk home industry yang masih bertahan di permukiman Kelurahan Keranggan yaitu berupa opak, enyek, keripiki pisang, dan keripik singkong. Dari seluruh area Kelurahan Keranggan, bagian permukiman Kelurahan Keranggan yang paling banyak memiliki home industry berada di RT 12 dan RT13, RW05; serta terletak dekat dengan jalan akses utama menuju permukiman Kelurahan Keranggan. Selain itu, lokasi permukiman tersebut berada di sepanjang sungai Cisadane.

Potensi home industry yang ada di permukiman Kelurahan Keranggan memang sangat beragam dan dapat menjadi salah satu upaya untuk pengembangan ekonomi lokal. Namun, untuk mengukur kinerja permukiman Kelurahan
Keranggan tidak cukup hanya dilihat dari potensi home industry saja, tetapi juga harus dilihat dari kualitas lingkungan. Kualitas lingkungan permukiman Keranggan masih sangat rendah. Hal ini terlihat dari banyaknya sampah yang berserakan di sekitar kawasan permukiman dan sepanjang sepadan sungai Cisadane. Sampah yang berserakan di sekitar area permukiman Kelurahan Keranggan didominasi oleh sampah plastic yang berasal dari sampah rumah tangga, dan sampah hasil produksi home industry.

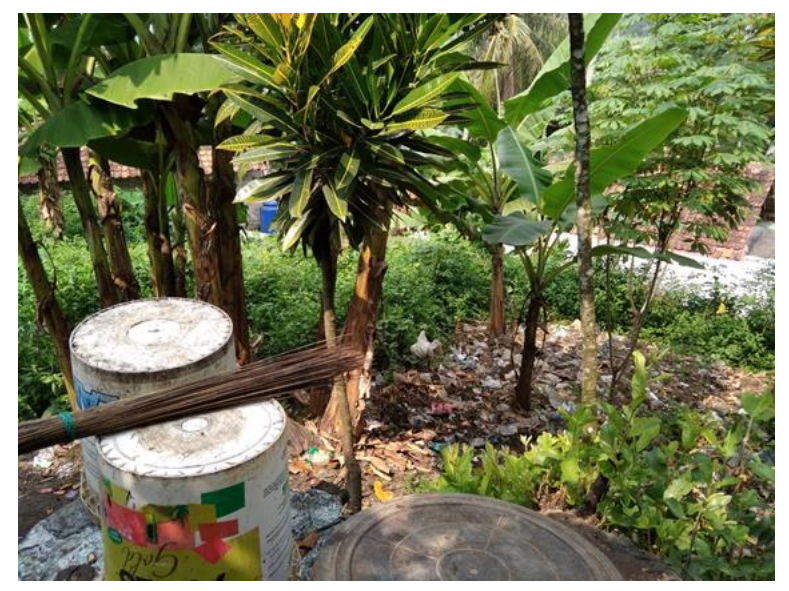

Gambar 1. Kondisi lingkungan permukiman di Kelurahan Keranggan yang berisi sampah yang berserakan di ruang terbuka sekitar permukiman.

Sumber: Dokumentasi penulis (2018)

Sampah yang berserakan di sekitar area permukiman Kelurahan Keranggan merupakan permasalahan yang buruk. Selain menimbulkan masalah lingkungan dan mengganggu kesehatan lingkungan serta masyarakat. Kemudian, adanya sampah yang berserakan di sekitar area permukiman menunjukkan bahwa pengelolaan sampah di permukiman Kelurahan Keranggan masih rendah. Rendahnya pengelolaan sampah di permukiman Kelurahan Keranggan tidak hanya disebabkan oleh perilaku masyarakat yang tidak peduli terhadap lingkungan, tetapi juga kurangnya pengetahuan masyarakat tentang cara mengelola sampah dengan baik dan benar, serta kurangnya peran dari stakeholder yakni Pemerintah Kota beserta dinas terkait seperti Dinas Lingkungan Hidup Kota Tangerang dalam menangani masalah sampah, khususnya di permukiman Kelurahan Keranggan.

Melihat fenomena diatas, muncullah ide dan gagasan untuk melakukan kegiatan pengabdian Lingkungan Hidup dan Kebencanaan 2 
kepada msyarakat melalui sosialisasi pengelolaan sampah berbasis partisipatif di Kelurahan Keranggan. Pendekatan partisipatif ini dilakukan melihat pada kebersamaan yang masih bertahan dan terwujud dalam home industry yang dilakukan oleh ibu-ibu rumah tangga . Dengan demikian, kegiatan pengelolaan sampah harus melibatkan seluruh masyarakat, khususnya pelaku usaha home industry. Tujuan kegiatan pengabdian masyarakat ini adalah untuk memotivasi dan mengedukasi masyarakat agar menyadari bahwa sampah perlu dikelola dengan baik. Selain itu adanya pengelolaan sampah yang baik, tidak hanya akan meningkatkan kualitas dan kesehatan lingkungan saja, tetapi juga meningkatkan kualitas hidup masyarakat dan dapat memberikan peluang tambahan pendapatan ekonomi masyarakat selain usaha home industry. Pengelolaan sampah yang baik dapat meningkatkan nilai guna sampah, yaitu sampah yang awalnya dianggap sebagai barang yang tidak berguna, tetapi dengan dikelola dengan baik, sampah dapat dibuat menjadi barang yang lebih bermanfaat. Dengan demikian, program pengabdian kepada masyarakat ini dilakukan secara bersamasama (partisipatif) supaya masyarakat di permukiman Kelurahan Keranggan memiliki persepsi dan paradigma yang sama tentang pentingnya mengelola sampah, serta sebagai langkah untuk membangun karakter dan mengedukasi masyarakat untuk senantiasa menjaga kebersihan lingkungan untuk menambah kualitas hidup (quality of life). Dengan adanya program pengabdian kepada masyarakat ini diharapkan mampu meningkatkan kinerja permukiman Kelurahan Keranggan melalui peningkatan kualitas produk home industry terjamin kebersihannya dan peningkatan kualitas lingkungan binaan.

\section{Tinjauan Pustaka}

\section{Tinjauan tentang Sampah}

Sampah adalah suatu benda atau bahan yang sudah tidak digunakan lagi oleh manusia sehingga dibuang. Stigma masyarakat terkait sampah adalah semua sampah itu menjijikan, kotor, dan lain-lain sehingga harus dibakar atau dibuang sebagaimana mestinya ( Mulasari dalam (Elamin, Muchammad Zamzam, et al, 2018). Sampah juga dapat didefinisikan sebagai limbah atau buangan yang bersifat padat, setengah padat yang merupakan hasil sampingan dari kegiatan perkotaan atau siklus kehidupan manusia, hewan, maupun tumbuhtumbuhan. Sumber limbah padat (sampah) perkotaan berasal dari permukiman, pasar, kawasan pertokoan dan perdagangan, kawasan perkantoran, dan sarana umum lainnya. Sampah secara umum dibagi menjadi dua yaitu sampah organik dan anorganik. Kedua sampah ini bermanfaat untuk kehidupan, namun juga ada dampaknya untuk lingkungan. Sampah organik adalah limbah yang berasal dari sisa mahluk hidup (alam) seperti hewan, manusia, tumbuhan yang mengalami pembusukan atau pelapukan. Sampah ini tergolong sampah yang ramah lingkungan karena dapat diurai oleh bakteri secara alami dan berlansungnya cepat. Sampah anorganik adalah sampah yang berasal dari sisa manusia yang sulit untuk diurai oleh bakteri sehingga membutuhkan waktu yang cukup lama (hingga ratusan tahun) untuk dapat diuraikan (Maulana,Fajar.M, Taufiq Agus, 2015).

Salah satu upaya untuk menyelesaikan permasalahan sampah adalah melakukan pengelolaan sampah yang dilakukan dengan prinsip 3R (reduce, reuse, dan recycle). 3R adalah prinsip utama mengelola sampah mulai dari sumbernya, melalui berbagai langkah yang mampu mengurangi jumlah sampah yang dibuang ke TPA (Tempat Pembuangan Akhir). Langkah utama adalah pemilahan sampah sejak dari sumber. Menurut Environmental Services Program dalam (Gutama Surya Arie, Darwis Saprudin Rudi, Sulistiyorini Rahmawati, 2015) kunci keberhasilan program kebersihan dan pengelolaan sampah terletak pada pemilahan. Pemilahan adalah memisahkan antara jenis sampah yang satu dengan jenis yang lainnya. Menurut (Olivia, Deasy, Setioko,Bambang, Purwanto,Edi, 2015) sampah terbagi atas 2 (dua) jenis yaitu sebagai berikut:

a) Sampah organik, terdiri dari bahan penyusun tumbuhan dan hewan yang diambil dari alam atau dihasilkan dari kegiatan pertanian, perikanan, dan lainlain. Sampah ini dengan mudah diuraikan dalam proses alami dan dapat diolah lebih lanjut menjadi kompos. Adapun yang termasuk sampah organik adalah sampah rumah tangga dari dapur (sampah makanan), sisa tepung, sayuran, kulit buah, dan daun-daun kering.

b) Sanpah anorganik, yaitu sampah yang tidak mudah dan bahkan tidak bisa membusuk. Sampah anorganik berasal dari sumber daya alam yang tidak dapat Lingkungan Hidup dan Kebencanaan 3 
diperbaharui seperti mineral dan minyak bumi, atau dari proses industri. Sebagian dari sampah anorganik secara keseluruhan tidak dapat diuraikan dari alam, sedang sebagian lainnya hanya dapat diuraikan dalam waktu yang lama. Sampah anorganik pada tingkat rumah tangga misalnya berupa botol plastik, tas plastik, plastik bekas kemasan, dan kaleng.

\section{Tinjauan tentang Pengelolaan Sampah}

Pengelolaan sampah meliputi beberapa cara, yaitu sebagai berikut (Gutama Surya Arie, Darwis Saprudin Rudi, Sulistiyorini Rahmawati, 2015):

a) Pengumpulan dan pengangkutan sampah yang dilakukan dengan mengadakan tempat khusus untuk mengumpulkan sampah. Kemudian, setelah dikumpulkan, sampah harus diangkut ke tempat penampungan sampah (TPS) dan selanjutnya ke tempat penampungan akhir (TPA).

b) Pemusnahan dan pengelolaan sampah Pemusnahan dan atau pengelolaan sampah dapat dilakukan melalui:

- Ditanam (landfill), yaitu pemusnahan sampah dengan membuat ladang di tanah kemudian sampah dimasukkan dan ditimbun dengan tanah.

- Dibakar (inceneration), yaitu memusnahkan sampah dengan jalan membakar di dalam tungku pembakaran (incenerator)

- Dijadikan pupuk (composting), yaitu pengolahan sampah menjadi pupuk kompos, khususnya untuk sampah organik daun-daunan, sisa makanan, dan sampah lain yang dapat membusuk. Apabila setiap rumah tangga dibiasakan untuk memisahkan sampah organik dan an-organik, kemudian sampah organik diolah menjadi pupuk tanaman. Sedangkan sampah an-organik dapat dibuang atau dimanfaatkan kembali untuk menjadi barang yang lebih bernilai.

- Penghancuran (pulverization)
Sampah yang berasal dari bak penampungan langsung dipotong menjadi potongan kecil. Kemudian, sampah tersebut dilumatkan untuk menimbun permukaan tanah yang rendah.

- Makanan ternak (hogfeeding)

Sampah organik seperti sayuran, ampas tapioka, dan ampas tahu dapat dimanfaatkan sebagai makanan ternak

- Pemanfaatan ulang (recycling)

Pemanfaatan ulang (recycling) sampah dilakukan pada beberapa contoh sampah an-organik seperti: kertas, pecahan kasa, botol bekas, logam, dan plastik. Sampah ini dapat dibuat menjadi karton, kardus pembungkus, alat-alat perangkat rumah tangga dari plastik dan kaca.

\section{Tinjauan tentang Pendekatan Partisipatif}

\subsection{Definisi Partisipasi}

Partisipasi merupakan bagian dari kegiatan pemberdayaan masyarakat (community development). Partisipasi dapat diartikan dengan keikutsertaan atau keterlibatan dari seorang individu atau masyarakat (Gutama Surya Arie, Darwis Saprudin Rudi, Sulistiyorini Rahmawati, 2015). Menurut Santosa dalam (Gutama Surya Arie, Darwis Saprudin Rudi, Sulistiyorini Rahmawati, 2015) partisipasi didefinisikan sebagai karakteristik mental/pikiran dan emosi/perasaan seseorang dalam situasi kelompok yang mendorongnya untuk memberikan sumbangan kepada kelompok dalam usaha mencapai tujuan serta turut bertanggungjawab terhadap usaha yang bersangkutan. Berdasarkan definisi tersebut dapat ditekankan bahwa partisipasi atau peran masyarakat merupakan suatu alat untuk mencapai tujuan, serta lebih menekankan pada aspek psikologis yang mendorong seseorang atau individu untuk melakukan tindakan tertentu dalam rangka mencapai tujuan.

Partisipasi dapat dilihat dari dua sisi yaitu sisi internal dan sisi eksternal. Partisipasi secara internal berarti adanya rasa memiliki terhadap komunitas. Sedangkan partisipasi dalam arti eksternal terkait dengan bagaimana individu melibatkan diri dengan komunitas luar (Erickson dalam (Muslim, 2007).

\subsection{Tipologi Partisipasi Masyarakat}

Menurut Arnstein dalam (Mawarni Dian,Sawitri Ayu Ida, Olivia, Deasy, Hardjasaputra,

$$
\text { Lingkungan Hidup dan Kebencanaan } 4
$$


Harianto, 2018) ada 8 (delapan) tipologi peran serta masyarakat yang dapat dilihat sebagai proses peran serta masyarakat, yaitu sebagai berikut:

\section{Manipulation}

Manipulasi adalah tingkatan peran serta masyarakat yang paling rendah. Pada tingkatan ini masyarakat hanya ditempatkan sebagai anggota dan hanya dijadikan alat publikasi dari pihak penguasa.

\section{Therapy}

Kegiatan-kegiatan yang dilakukan pada tahap ini hanyalah usaha untuk mengubah pola pikir masyarakat, bukan untuk mendapatkan saran dan masukan dalam membuat program-program pengembangan.

\section{Informing}

Tahap ini merupakan tahap awal komunikasi dengan masyarakat, yaitu memberikan pengetahuan mengenai hak-hak,tanggung jawab dan pilihan yang dapat diambil oleh masyarakat untuk mengembangkan diri.

\section{Consultation}

Langkah ini merupakan tahapan yang penting dilakukan dalam mencapai komunikasi dua arah dengan masyarakat, di mana masukan-masukan dari masyarakat menjadi ide program untuk pengembangan.

\section{Placation}

Penunjukkan beberapa masyarakat yang berpengaruh dalam lingkungannya untuk menjadi badan kerja. Sistem ini memungkinkan usulanusulan masyarakat dapat dikemukakan dengan baik melalui perwakilannya.

\section{Partnership}

Adanya pembagian kekuasaan antara masyarakat dengan penginisiasi program. Keduanya menyepakati untuk saling berbagi tanggung jawab baik dalam proses perencanaan hingga pemecahan persoalan.

\section{Delegated power}

Pada tahap ini masyarakat diberikan kewenangan untuk membuat keputusan/program sesuai dengan kebutuhannya. Masyarakat memiliki kewenangan penuh untuk membuat programprogram pembangunan.

\section{Citizen control}

Pada tahap ini masyarakat dapat mengatur program, kelembagaan, dan kendali untuk kepentingan masyarakat itu sendiri. Masyarakat memiliki kewenangan penuh dalam pemegang dana.
3.3. Hubungan Pengelolaan Lingkungan dan Partisipasi Masyarakat

Pengelolaan lingkungan merupakan upaya yang melibatkan berbagai kepentingan. Namun kenyataannya upaya tersebut seringkali kurang berhasil. Kurang berhasilnya upaya pengelolaan yang dilakukan selama ini karena tidak melibatkan masyarakat lokal dalam mata rantai pengambilan keputusan (Hadi, 2013).

Sebagai langkah untuk melakukan pengelolaan lingkungan, khususnya sampah; maka model pengelolaan lingkungan yang sekarang ini sedanga banyak dilakukan berupa model proaktif dengan mendayagunakan potensi masyarakat (Hadi, 2013). Model pengelolaan lingkungan proaktif ini dapat dimodifikasi menjadi strategi pengendalian bersama (co-management) yang "proaktif" dengan mengikutsertakan masyarakat menjadi bagian dari sistem pengendalian lingkungan. Dalam hal ini masyarakat lokal menjadi asset berharga (Hadi, 2013). Sebagai sub sistem, masyarakat lokal kaya akan informasi keseharian yang oleh Linblom dalam (Hadi, 2013) dipuji sebagai "usable knowledge" yang berguna bagi pengelolaan dan perencanaan pembangunan. Pengelolaan lingkungan yang proaktif juga memerlukan kesamaan persepsi masyarakat terhadap lingkungan.Persepsi tentang lingkungan adalah interpretasi tentang suatu setting individu didasarkan pada latar belakang budaya, nalar, dan pengalaman individu tersebut ( Haryadi dan Setiawan dalam Olivia, 2018)

\section{METODE}

Kegiatan pengabdian kepada masyarakat ini menggunakan metode sosialisasi dengan pendekatan partisipatif. Sosialisasi dilakukan dengan memberikan informasi tentang cara mengelola sampah ke seluruh warga di permukiman Kelurahan Keranggan dari rumah ke rumah warga, khususnya bagi warga yang memiliki usaha rumahan (home industry). Tahapan yang dilakukan dalam kegiatan ini adalah sebagai berikut: 


\begin{tabular}{|c|}
\hline Penentuan Lokasi Sosialisasi \\
\hline $\begin{array}{l}\text { Observasi kondisi kawasan permukiman yang } \\
\text { berpotensi memiliki sampah home industry } \\
\text { dalamjumlah banyak }\end{array}$ \\
\hline $\begin{array}{l}\text { Pendataan potensi dan masalah terkait } \\
\text { ketidakberhasilan pengelolaan sampah di } \\
\text { permukiman Kelurahan Keranggan }\end{array}$ \\
\hline $\begin{array}{l}\text { Pembuatan poster terkait pengelolaan sampah } \\
\text { home industry menggunakan media yang } \\
\text { informatif }\end{array}$ \\
\hline $\begin{array}{l}\text { Koordinasi dengan pengurus RW dan pihak } \\
\text { Kelurahan Keranggan terkait sosialisasi }\end{array}$ \\
\hline $\begin{array}{l}\text { Melakukan sosialisasi ke rumah-rumah warga } \\
\text { pelaku home industry }\end{array}$ \\
\hline $\begin{array}{l}\text { Memasang poster informatif di seluruh rumah } \\
\text { warga yang telah mendapatkan sosialisasi }\end{array}$ \\
\hline
\end{tabular}

Gambar 2. Tahapan Kegiatan Pengabdian Kepada Masyarakat Sosialisasi Pengelolaan Sampah di Kelurahan Keranggan Sumber: Penulis (2018)

\section{Lokasi Kegiatan Pengabdian Kepada Masyarakat}

Kegiatan pengabdian kepada masyarakat tentang pengelolaan sampah home industry dilaksanakan di permukiman Kelurahan Keranggan RT 012 dan RT 013. Kawasan permukiman Kelurahan Keranggan RT012 dan RT013 merupakan kawasan permukiman yang memiliki didominasi oleh masyarakat yang bekerja sebagai pelaku usaha home industry. Kemudian, permukiman Kelurahan Keranggan terletak di Kecamatan Setu dan merupakan salah satu permukiman desa yang masih bertahan, termasuk potensi usaha home industry.

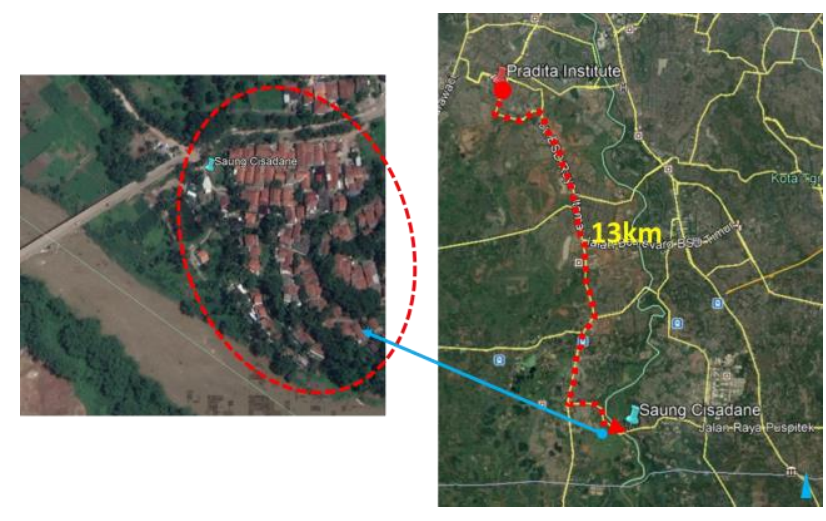

Gambar 3. Peta Lokasi Permukiman Kelurahan Keranggan

Sumber: Olah Penulis (2018)

Berdasarkan pemetaan zonasi home industry yang telah dilakukan pada kegiatan pengabdian masyarakat sebelumnya serta melihat dari potensi yang ada di permukiman Kelurahan Keranggan, sebaran rumah warga yang merupakan rumah usaha home industry terletak di RT012 dan RT013 dimana posisi kawasan permukiman ini letak dekat dengan jalan utama permukiman dan sebaran rumah industri mengikuti aliran sungai Cisadane.

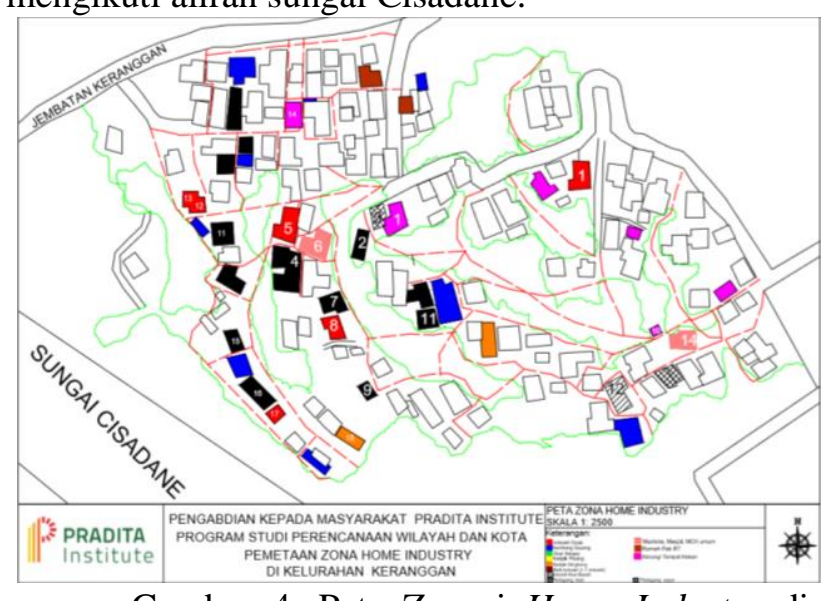

Gambar 4. Peta Zonasi Home Industry di Kelurahan Keranggan.

Sumber: Analisa Penulis (2018) 
Usaha home industry yang ada di permukiman Kelurahan Keranggan berupa usaha makanan tradisional berupa keripik pisang, keripik singkong, opak, dan enyek.
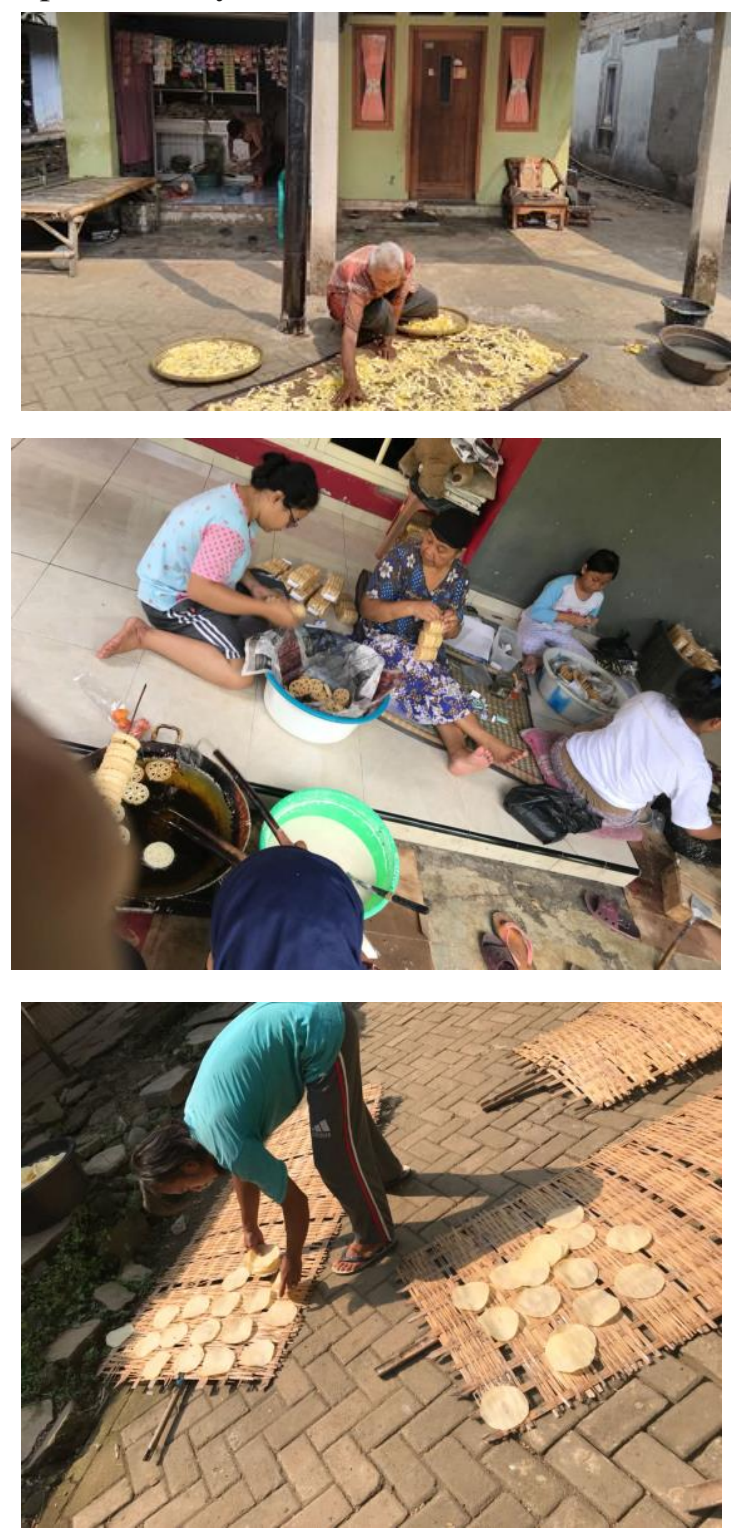

Gambar 5. Usaha Home Industry Di Permukiman Kelurahan Keranggan RT012 dan RT013

Sumber: Dokumentasi penulis (2018)

\section{HASIL DAN PEMBAHASAN}

Kegiatan pengelolaan sampah home industry berbasis partisipatif diawali dengan melakukan pendataan tentang potensi home industry yang ada di permukiman Kelurahan Keranggan. Setelah mendapatkan data tentang jenis home industry, pendataan kembali dilakukan untuk mengetahui jenis sampah lainnya yang ada di permukiman Kelurahan Keranggan. Adapun jenis sampah lainnya yang belum terkelola dengan baik yakni sampah rumah tangga berupa bungkus makanan dan botol air mineral.

Kegiatan pengabdian kepada masyarakat berupa sosialisasi pengelolaan sampah berbasis partisipatif di Kelurahan Keranggan dilakukan bersama antara dosen dan mahasiswa dengan cara mendatangi rumah warga yang merupakan pelaku usaha home industry dan telah didata serta dipetakan sebelumnya. Kegiatan pengelolaan sampah berbasis partisipatif dilakukan dalam bentuk media informatif berupa poster yang dipasang di setiap rumah warga.

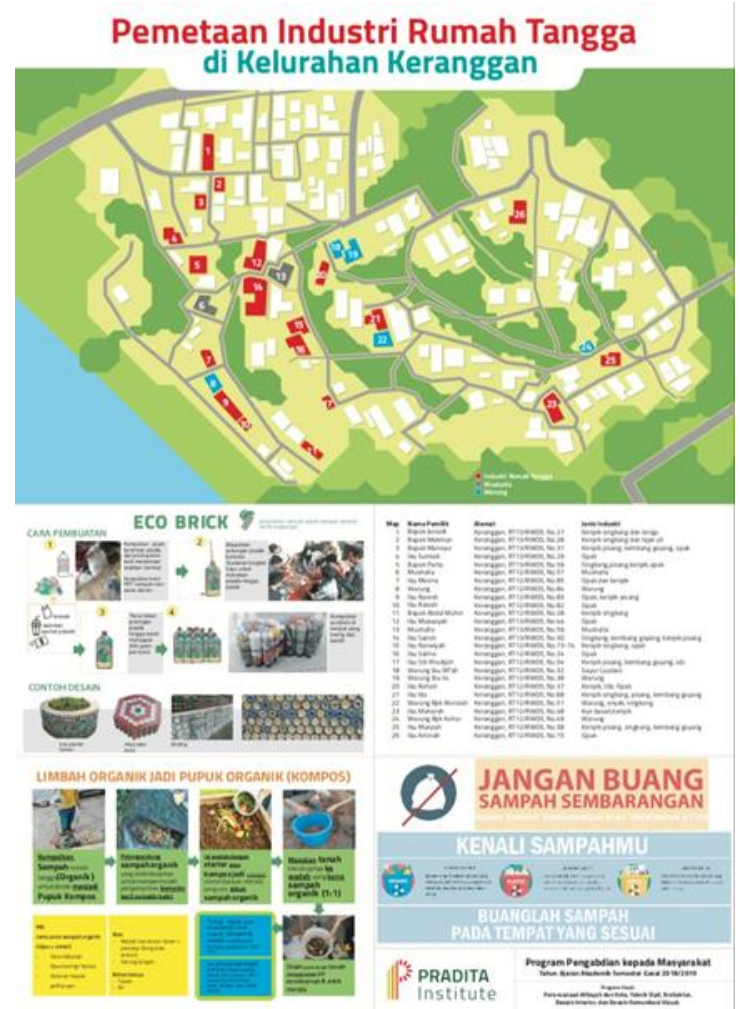

Gambar 6. Penggunaan Poster sebagai Media Informatif dalam Pelaksanaan Kegiatan Pengabdian Kepada Masyarakat, Pengelolaan Sampah Home Industry Berbasis Partisipatif di Kelurahan Keranggan.

Sumber: penulis (2018)

Langkah yang dilakukan setelah melakukan pendataan tentang potensi home industry dan permasalahan sampah home industry, pelaksanaan kegiatan pengelolaan sampah berbasis partisipatif dilakukan dengan membangun koordinasi dengan Lingkungan Hidup dan Kebencanaan 7 
pihak stakeholder Kelurahan Keranggan, yakni sekretaris lurah beserta staff, perwakilan pengurus koperasi Saung Cisadane sebagai pengelola usaha home industry, bapak RW dan beberapa perwakilan tokoh masyarakat di permukiman Kelurahan Keranggan.
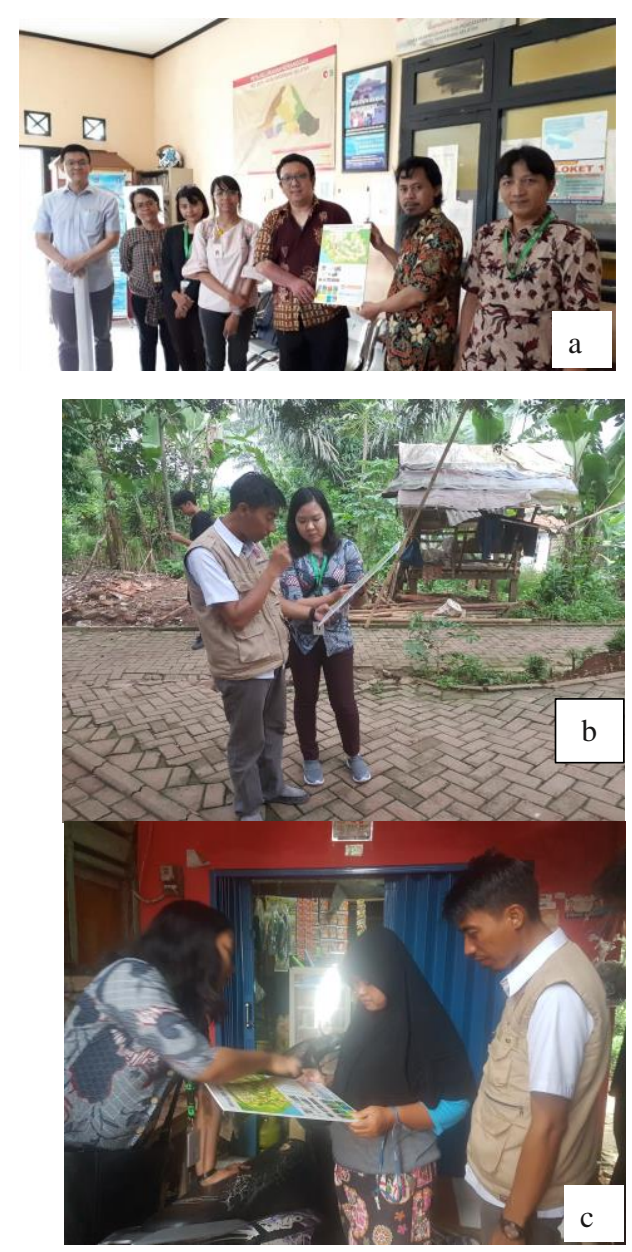

Gambar 7. Koordinasi antar pemangku kepentingan dalam menginformasikan kegiatan pengelolaan sampah berbasis partisipatif di Kelurahan Keranggan. [a] koordinasi dengan pihak Kelurahan Keranggan,[b] koordinasi dengan perwakilan pengelola koperasi,[c] koordinasi dengan perwakilan tokoh masyarakat.

Sumber: Dokumentasi penulis (2018)

Dalam pelaksanaan kegiatan pengabdian kepada masyarakat yang dilakukan dosen bersama mahasiswa dilakukan dengan memberikan materi sosialisasi pengelolaan sampah dari rumah ke rumah warga, khususnya warga pelaku usaha home industry.

Koordinasi yang dilakukan dalam pelaksanaan program pengabdian kepada masyarakat ini tidak hanya dilakukan oleh dosen beserta stakeholder di Kelurahan Keranggan, tetapi juga dilakukan oleh dosen dan mahasiswa sebelum turun ke lokasi kegiatan pengabdian kepada masyarakat. Tujuannya adalah untuk menyamakan persepsi dan tujuan serta mekanisme pelaksanaan kegiatan pengabdian kepada masyarakat terkait pengelolaan sampah berbasis partisipatif.
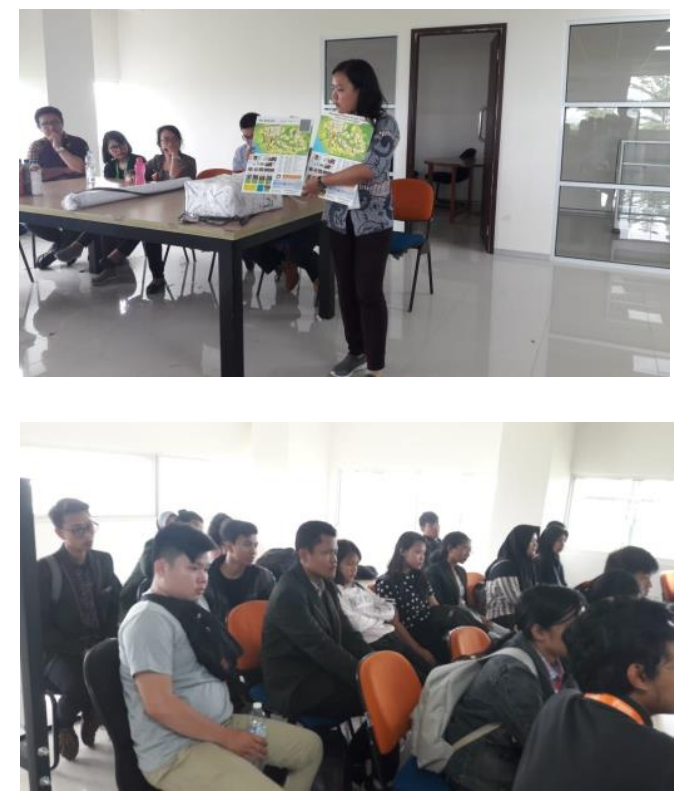

Gambar 8. Koordinasi pelaksanaan kegiatan pengabdian kepada masyarakat antara dosen dan mahasiswa terkait mekanisme pelaksanaan kegiatan PkM

Sumber: Dokumentasi penulis (2018)

Mekanisme pelaksanaan kegiatan pengabdian kepada masyarakat tentang pengelolaan sampah berbasis partisipatif di Kelurahan Keranggan dilaksanakan melalui beberapa tahap yaitu sebagai berikut: 
1. Pemberian materi sosialisasi kepada warga tentang pengenalan jenis sampah dan cara mengelola (memilah) sampah.
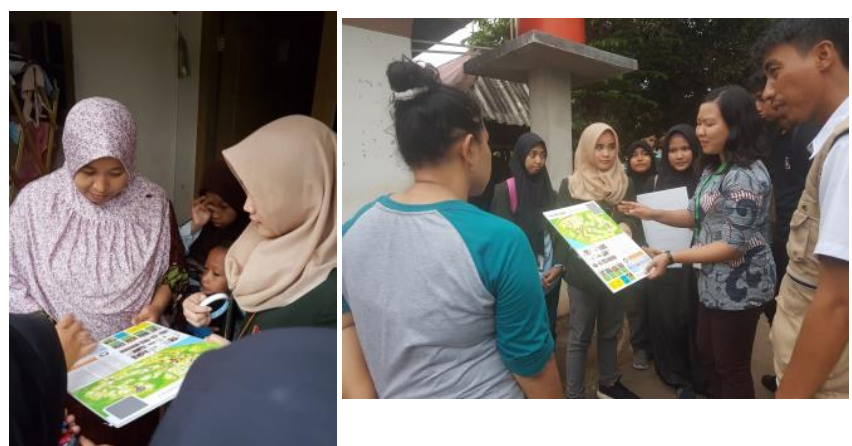

Gambar 9. Pemberian materi sosialisasi tentang pengelolaan sampah home industry kepada masyarakat di Kelurahan Keranggan Sumber: Dokumentasi Penulis (2018)

2. Pengambilan foto bagi warga yang telah mendapatkan sosialisasi.

Sebagai bukti bahwa warga telah mendapatkan sosialisasi tentang cara mengelola sampah home industry, maka dosen dan mahasiswa yang telah memberikan materi tentang cara mengelola sampah, dan mengambil gambar warga menggunakan kamera polaroid, dimana hasil fotonya bisa langsung jadi dan dipasang pada poster sosialisasi.

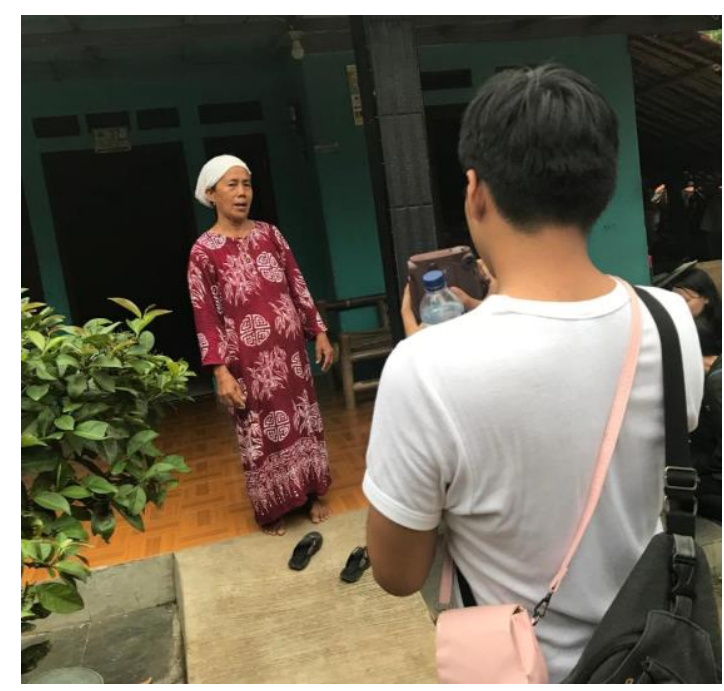

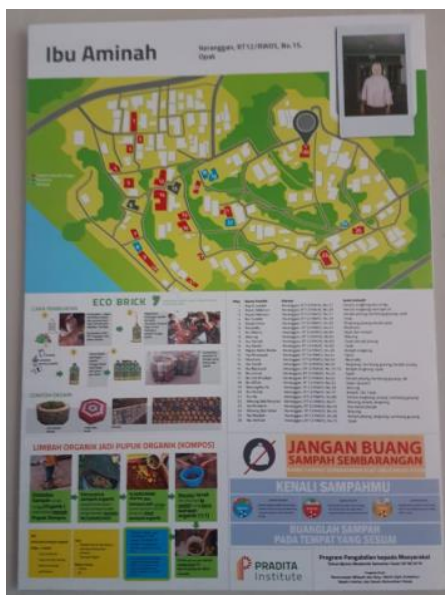

Gambar 10. Aktualisasi poster informative sebagai media sosialisasi pengelolaan sampah berbasis partisipatif di Kelurahan Keranggan

Sumber: Dokumentasi Penulis (2018)

3. Pemasangan poster sosialisasi di rumah warga Kelurahan Keranggan

Sebagai bagian dari sosialisasi pengelolaan sampah berbasis partisipatif di Kelurahan Keranggan, tahap selanjutnya adalah dosen bersama dengan mahasiswa dan warga memasang poster sosialisasi. Tujuannya adalah untuk mengedukasi warga tidak hanya sekedar sosialisasi saja, tetapi juga memberikan pemahaman kepada warga melalui media informative poster yang berisi tentang jenis-jenis sampah serta cara mengelola (memilah) sampah dan 
mengolah sampah menjadi barang yang lebih bernilai dan ramah lingkungan.
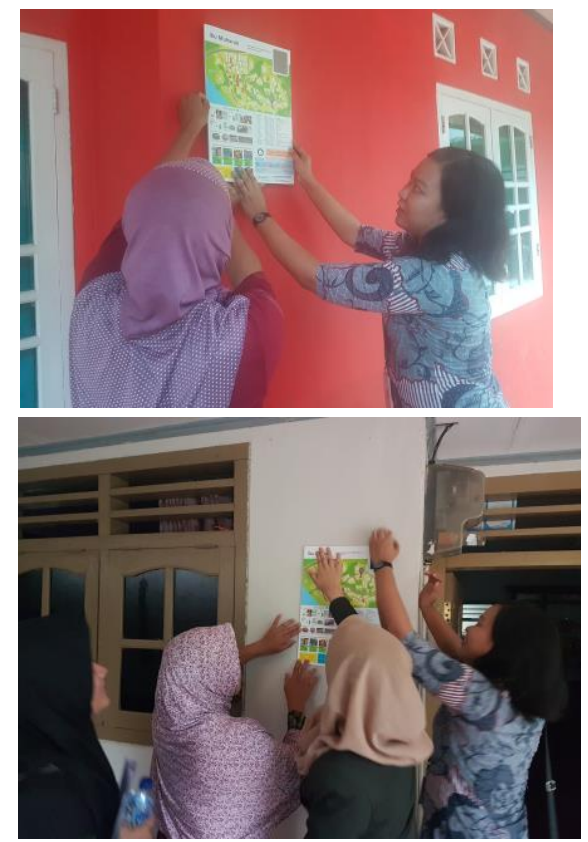

Gambar 11. Pemasangan poster bersama warga sebagai media sosialisasi pengelolaan sampah home industry berbasis partisipatif di Kelurahan Keranggan

Sumber: Dokumentasi Penulis (2018)

Berdasarkan kegiatan pengabdian kepada masyarakat terkait pengelolaan sampah berbasis partisipatif di Kelurahan Keranggan, tipologi partisipasi masyarakat yang terjadi ada di posisi:

1. Informing

Tahap informing ini dilakukan dalam bentuk sosialisasi pengelolaan sampah home industry kepada masyarakat. Sosialisasi ini dilakukan dengan cara mendatangi rumah warga dari rumah ke rumah, warga diberikan pengetahuan dan pemahaman mulai dari cara mengenali sampah berdasarkan jenis sampahnya. Kemudian, warga juga diedukasi tentang cara memilah sampah berdasarkan jenis sampah yakni sampah organic dan sampah non organic. Sosialisasi ini menggunakan media informative dan dilengkapi dengan gambar, sehingga memudahkan warga untuk memahami materi sosialisasi yang diberikan.

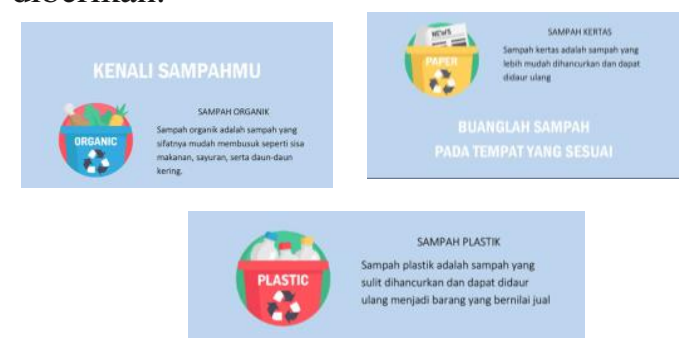

Gambar 12. Informasi cara mengenali sampah dan memilah sampah yang dikemas dalam media informative Sumber: Penulis (2018)
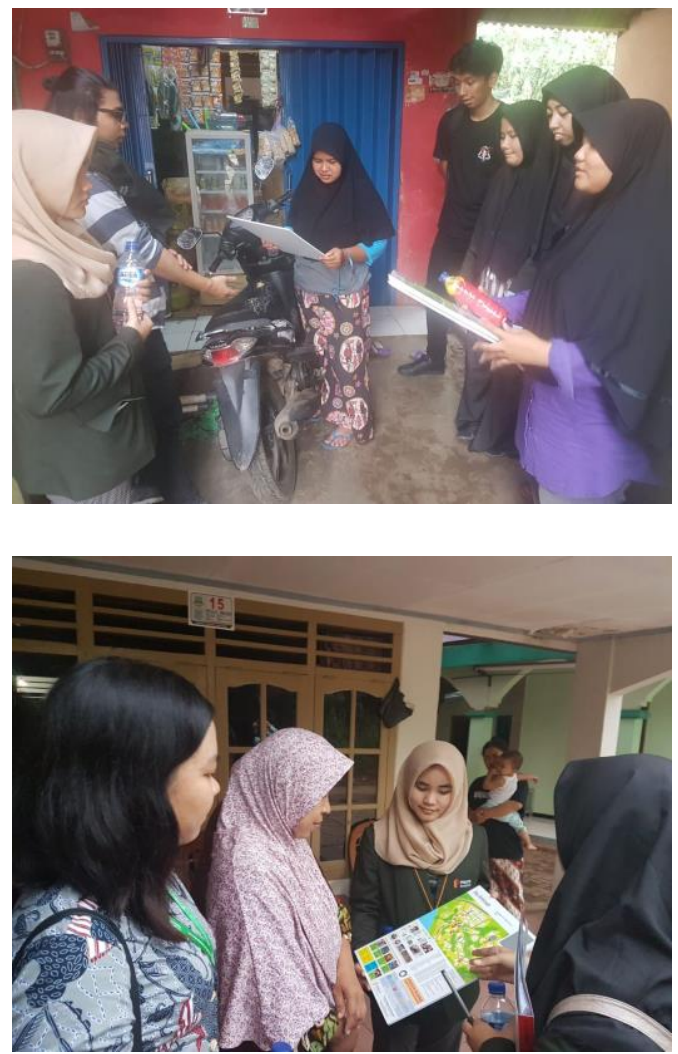

Gambar 13. Tahap informing berupa komunikasi dan memberikan pengetahuan tentang jenis sampah dan cara mengelola sampah home industry di Kelurahan Keranggan

Sumber: Dokumentasi penulis (2018)

Berdasarkan teori tentang cara mengelola sampah, maka sampah yang ada di

Lingkungan Hidup dan Kebencanaan 10 
Kelurahan Keranggan, khususnya sampah home industry, cara mengelola sampah yang dapat diterapkan adalah dengan cara dipilah menurut jenis sampahnya. Lalu setelah warga mampu memilah sampah dengan benar sesuai jenis sampahnya, baru sampah tersebut dikelompokkan ke dalam tempat sampah sesuai dengan jenis sampah. Bagi sampah organic, seperti sisa sayur, kulit singkong, dan kulit pisang sisa industri dapat ditanam dan dijadikan pupuk organic berupa pupuk kompos. Selain itu, bagi sampah sisa makanan dapat juga dijadikan sebagai makanan ternak. Sedangkan sampah non organic seperti botol minuman dapat didaur ulang kembali dan menjadi barang yang lebih bernilai manfaat bagi masyarakat.

\section{Consultation}

Langkah dilakukan dalam bentuk diskusi bersama masyarakat saat sosialisasi pengelolaan sampah home industry berbasis partisipatif di Kelurahan Keranggan sedang berlangsung. Pada kegiatan pengabdian kepada masyarakat ini, selama sosialisasi tidak hanya sekedar menyampaikan materi tetapi juga ada diskusi antara pemateri (dosen dan mahasiswa) dengan warga dan pemangku kepentingan dari pihak kelurahan Keranggan. Diskusi ini merupakan awalan untuk menyusun program bersama pihak Kelurahan Keranggan bersama masyarakat dan Institut Sains dan Teknologi Pradita untuk mewadahi masyarakat dalam pengelolaan sampah, khususnya sampah home industry agar lebih terkelola.

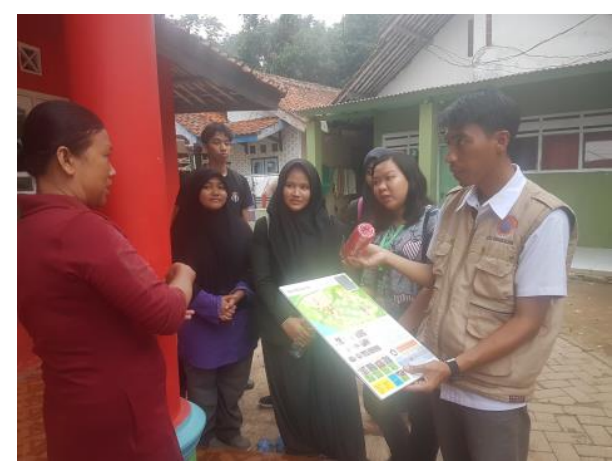

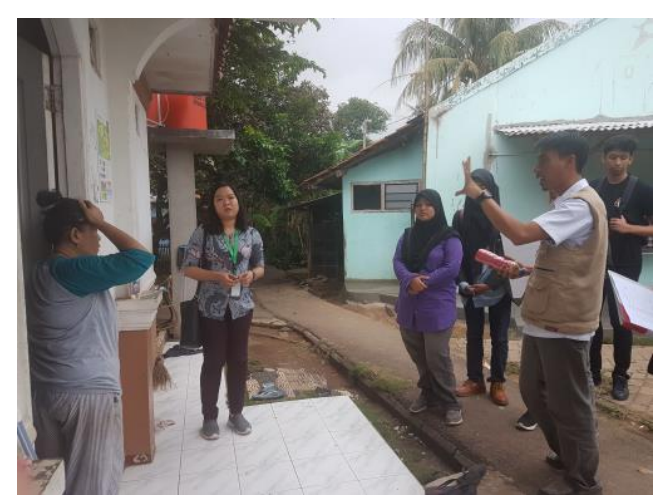

Gambar 14. Bentuk konsultasi dan sosialisasi yang dilakukan antara dosen dan mahasiswa bersama warga dan pihak Kelurahan Keranggan dalam pengelolaan sampah home industry di Kelurahan Keranggan.

Sumber: Dokumentasi penulis (2018)

\section{KESIMPULAN}

Berdasarkan hasil kegiatan pengabdian kepada masyarakat tentang pengelolaan sampah home industry berbasis partisipatif dapat disimpulkan bahwa kegiatan pengelolaan sampah tidak hanya sekedar memilah sampah secara fisik, akan tetapi memerlukan partisipasi masyarakat. Selain itu, untuk mewujudkan pengelolaan sampah yang baik dan benar, masyarakat perlu diedukasi dan diberikan pengetahuan serta pemahaman yang benar tentang cara mengelola sampah berdasarkan jenis sampah. Terkait dengan home industry, pengelolaan sampah perlu disesuaikan berdasarkan jenis home industry yang ada di Kelurahan Keranggan, agar sampah sisa industry tidak terbuang begitu saja, melainkan mampu memberikan manfaat bagi lingkungan setempat dan meningkatkan kualitas hidup masyarakat. Selain itu, dalam pengelolaan sampah, khususnya sampah home industry perlu adanya keterlibatan pemangku kepentingan untuk mewadahi pengelolaan sampah agar dapat memberikan peluang untuk meningkatkan kualitas hidup masyarakat melalui pengelolaan sampah. Oleh karena itu, pada program pengabdian kepada masyarakat selanjutnya, dapat dilakukan kegiatan yang tetap berbasis partisipatif dengan membuat system manajemen pengelolaan sampah home industry melibatkan masyarakat dan pemangku kepentingan, dimana masyarakat diajarkan tentang 
system manajemen sampah serta membuat layout penataan tempat sampah komunal di permukiman Kelurahan Keranggan.

\section{UCAPAN TERIMAKASIH}

Penulis mengucapkan terima kasih kepada Institut Sains dan Teknologi Pradita yang telah mendukung kegiatan pengabdian kepada masyarakat. Penulis juga mengucapkan terima kasih kepada pihak perangkat, masyarakat, dan koperasi Kelurahan Keranggan yang telah bekerja sama untuk membina, desa Keranggan sebagai desa home industry.

\section{REFERENSI}

Elamin, Muchammad Zamzam, et al. (2018, Oktober). Analisis Pengelolaan Sampah Pada Masyarakat Desa Disanah Kecamatan Sreseh Kabupaten Sampang, Analysis Of Waste Management In The Village of Disanah, District of Sreseh, Sampang, Madura. Jurnal Kesehatan Lingkungan, 10, No.4, 369.

Gutama Surya Arie, Darwis Saprudin Rudi, Sulistiyorini Rahmawati. (2015). Partisipasi Masyarakat Dalam Pengelolaan Sampah Lingkungan Margaluyu Kelurahan Cicurug. Share Social Work Jurnal, 5 , No 1, 75.

Hadi, P. S. (2013). Manusia dan Lingkungan. Semarang: Badan Penerbit Undip.

Maulana,Fajar.M, Taufiq Agus. (2015, Januari 1). Sosialisasi Sampah Organik dan Non Organik Serta Pelatihan Kreasi Sampah. Jurnal Inovasi dan Kewirausahaan, 4, 6873.

Mawarni Dian,Sawitri Ayu Ida, Olivia, Deasy, Hardjasaputra, Harianto. ( 2018). Mengelola Peran Serta Masyarakat Untuk Peningkatan
Kualitas Hidup:Perencanaan Partisipatif. Konferensi Nasional Pengabdian Kepada Masyarakat dan Corporate Social Responsibility, Optimalisasi Peran Perguruan Tinggi Dan Dunia Usaha Dalam Pemulihan Pasca Bencana Lombok (pp. 1401-1410). Mataram: Penerbit Universitas Multimedia Nusantara.

Muslim, A. (2007, Desember). Pendekatan Partisipatif Dalam Pemberdayaan Masyarakat. Aplikasia, Jurnal Aplikasi Ilmu-Ilmu Agama, VIII, No.2, 89-103.

Olivia, Deasy, Setioko,Bambang, Purwanto,Edi. (2015). Faktor-Faktor Pembentuk Kinerja Permukiman Sebagai Antisipasi Perwujudan Kampung Wisata Bahari (Studi Kasus: Kampung Nelayan Tambak Lorok Semarang). Penelitian Strategis Hibah Bersaing Dana DIPA Fakultas Teknik UNDIP Tahun Anggaran 2015, Universitas Diponegoro, Jurusan Arsitektur, Fakultas Teknik, Semarang.

Olivia, D., Setioko, B., \& Pandelaki, E. E. (2018). Analisa Faktor Pembentuk Karakteristik Sebaran Sarana dan Prasararana Permukiman Di Wilayah Perbatasan (Studi Kasus : Kelurahan Sendang Mulyo Kota Semarang). TEKNIK, Vol.39 (2)pp.106-113

Setiawan, Ari Zaki. (2018)."Dalam Sehari, Kota Tangerang Selatan Memproduksi 300 Ton Sampah". Wartakotalive.com, 26 Oktober 2018.

Tohir, Rahman Jaisy. (2019)."Warga Tangsel Buang Sampah 300 Ton Sehari, TPA Cuma Kuat Tampung Setahun Lagi". TribunJakarta.com, 03 Januari 2019. 
Prosiding PKM-CSR, Vol. 2 (2019)

e-ISSN: 2655-3570 